\title{
THE DRIVE FOR QUALITY - THE IMPACT ON ACCOUNTING IN THE WINE INDUSTRY
}

\author{
John Blake \\ Department of Accounting and Financial Services \\ University of Central Lancashire (England) \\ Oriol Amat \\ Universitat Pompeu Fabra (Barcelona, Spain) \\ Soledad Moya \\ Universitat Pompeu Fabra (Barcelona, Spain)
}

This study was undertaken with financial support from Miguel Torres, S.A. 


\section{$\underline{\text { ABSTRACT }}$}

THE DRIVE FOR QUALITY - THE IMPACT ON ACCOUNTING IN THE WINE INDUSTRY

\section{OVERVIEW}

There is a substancial literature on the accounting procedures needed to track down the costs of quality control and quality failure. In a drive for improved quality the changes in the process of production or service delivery will also give rise to new accounting needs. In this article we take one example of an industry, wine production, where in most countries there has been a movement towards expanding higher quality production. We report on interviews with wine producers in the US, Australia, Canada, New Zealand and Spain, and identify a variety of ways in which

a more sophisticated approach to accounting has become necessary as a result of the drive for quality. 


\section{THE DRIVE FOR QUALITY - THE IMPACT ON ACCOUNTING IN THE WINE INDUSTRY OVERVIEW}

In this paper we take an exanple of an industry, wine production, where in a number of countries there has been a movement towards expanding higher quality production. We report on interviews with wine producers in the US, Canada, Australia, New Zealand and Spain, and identify a variety of ways in which a more sophisticated approach to management accounting has become necessary as a result of the drive for quality.

Bloom et al (1994) have argued the vital role of the pursuit of quality in influencing management and accounting systems:

"The emphasis on quality involves co-operation, not only within a firm, but also with suppliers and customers. These concepts are associated with strategies such as Just-in-Time (JIT) manufacturing and with computer integrated manufacturing systems. All of these technological changes are based, for effectiveness, on concepts of continuous learning, team work, and flexibility... No longer can accounting be considered a neutral and objective function independent of political power and social

concerns. Nor can accounting possibly focus safely on functional tasks without addressing social and economic consequences of accounting standards. (p 44). 
Accounting issues arising from the move to quality in the wine industry include:

1. Valuation problems of higher quality grapes.

2. Cost allocations between a wider range of products

3. Longer maturing periods give rise to questions of whether finance costs should be imputed to inventory, and also exacerbate the distortion of stock values arising from inflation.

4. Higher quality wine production involves using barrels of different costs and useful lives.

5. Higher quality wines call for more sophistication in price setting.

6. There is a danger that a tax regime that operates fairly for bulk low quality production will inadvertently discriminate against higher quality production.

\section{The Accounting Problems}

The question of what constitutes an equitable level of excise duty on wine has been extensively debated both in relation to the contrast between high quality and lower quality wines and in relation to tbe treatment of wine compared to other forms of 
alcohol. Our survey indicates that there is also an inconsistency in the impact of income taxes on the profits of higher quality as compared to lower quality wines. This arises because:

1. High quality wine is held in stock over periods so long that, even in times of low inflation, there is a material difference between the historic cost of wine sold and the replacement cost at the point of sale. To maintain the operating capability of the business it is necessary to replace stock at this higher current replacement cost, and since there is no tax relief on this necessary increased working capital requirement it must be met out of the after tax profit. Low quality wine prodution, with short stockholding periods, does not face this problem.

2. In most jurisdictions the tax authorities require that barrels be treated as a fixed asset and amortised for tax purposes over a standard prescribed asset life, either on a straight line or a reducing balance basis. For a high quality winemaker the barrel serves two purposes, in the first two or three years of use the oak supplying key elements of flavour to the wine and subsequently, when these are largely extracted, having a much lower value as a simple storage vessel. The tax system fails to allow for the heavy true depreciation of the barrels in those early years. Low quality producers buying cheap barrels, sometimes second-hand from high quality producers, use the barrel consistently for storage and so are more fairly treated by the tax system. 
In tbe published financial accounts the higher quality producer also suffers from the failure of historic cost accounts to present a meaningful picture of the cost of inventory. There are two reasons for this:

1. As we have already seen when discussing the tax problem, historic cost accounts fail to uplift inventory values in line with inflation.

2. While stock is held by the business it must be financed. It is not normal in historic cost accounting to impute to stock the costs of the related finance, yet tbese costs are material when accumulated over a number of years.

These issues are not a problem for the low quality producer, with inventory held only briefly.

There is an interesting question as to what extent such distortions matter. There is extensive evidence to support the 'Efficient Market Hypotesis' that for stock market listed companies the market is capable of recognising and allowing for accounting distortions. (For a comprehensive review of tbis literature see Keane 1983). By contrast, evidence of the ability of bank financial analysts to identify such distortions is sketchy and tends to be negative. To take two examples:

1. One of the most difficult areas of accounting policy choice is in the treatment of research and development expenditure. McGee (1984) tested analysts' response in the USA to two sets of accounts which presented the position of one 
company; in one case, development costs were shown as an asset, in the other these costs were written off as incurred. Bank analysts showed a strong preferene for the company with these costs shown as an asset, while stock market analysts saw that the underlying economic position in both cases was identical and valued the company similarly in each case.

2. Another controversial accounting area is that of assets held under finance leases where to follow legal form would involve simply showing each year's rent in the profit and loss account while to follow comercial substance involves showing both the lease obligation and the related assets on the balance sheet. The latter treatment would suggest a higher geared company to the "naive" analyst who did not appreciate that the difference was on purely of accounting treatment, not of the underlying economic reality. Studies of share price reactions to finance lease capitalisation indicate that the market is not influenced by the accounting policy issue (see Abdel-Khalik 1981) while studies of bank analysts response to accounts presented on each basis indicate that they are influenced by tbe accounting treatment. (See Abdel-Khalik (1981) for the USA; Wilkins \& Zimmer (1983) for Singapore; Blake et al (1995) for Spain).

In our survey an interesting contrast between California and New Zealand emerged. In California the banks have developed their own system for assessing tbe value of inventory as security for lending. They have analysed wine by age and type on a broad brush basis, and allocate estimated market values accordingly. They have 
been lending up to $50 \%$ of such values but, in the light of satisfactory experience of this approach, are now tending to uplift tbis to $60 \%$.

By contrast, in New Zealand wine producers report that banks are reluctant to accept that historic cost accounting figures for quality wine inventory are substantially below market value. One finance director explained that his company was currently in protracted negotiations with the bank to achieve recognition of this issue. The more developed financing approach in the USA may be linked to the earlier move to higher quality wines in that country.

Our survey highlighted a range of problems in devising a system to support management decision making within the context of the historic cost accounting system:

1. All the companies we visited both grew their own grapes and bought in grapes from other suppliers. A range of problems, discussed below, arose in attributing a value to their own product.

2. Both for price setting and allocation of profit the omission of imputed interest and the inflation effect from inventory valuation is misleading.

3. Allocation of barrel costs in relation to actual usage is needed if the full cost of high quality product is to be identified

4. The pursuit of quality leads to a larger brand range, and a consequent need to allocate total costs between these brands. 
Overall, our survey indicates tbe need for substantial adaptation of normal historic cost accouting principles if the wine industry is to have an equitable basis for income tax, publish fair and meaningful financial accounts, and enjoy management information that is truly relevant to decision making in the context of high quality production. There are a number of examples from a range of countries where normal accounting principles have been adapted to meet the needs of specific industries. To give two examples:

1. In the USA sugar and tropical fruit producers have been explicitly exempted from a general requirement to value inventory on a total absortion cost basis, instead being allowed to use a marginal cost approach. The concession, by both tax authorities and accounting regulators, was a response to vigorous lobbying by producers in Hawaii who commissioned a report on the adverse economic impact on the state that would arise from higher taxes on their industry. (See Slepian 1985 for a full account).

2. In the UK investment property companies successfully lobbied for a change to a proposed accounting standard on depreciation so that investment properties in the UK are now subject to annual revaluation rather than being depreciated The reason for this lobbying was that, in the special case of the property industry, depreciation would have reduced profits to a level that would not sustain adequate dividend payments. (Milnes \& Tillett 1978). 
We therefore turn to each of the problem areas we have identified and, on the basis of the various nacional practices we have observed in our survey, suggest some possible solutions specific to high quality producers.

\section{Grape Valuation}

All but one of the companies we visited used a mixture of grapes they grew themselves and grapes bought in from outside suppliers. In New Zealand we noted a move by the leading producers to expand their own grape production, the two reasons given being:

1. The need to meet expanding demand.

2. The desire to control quality of production.

Two approaches to the valuation of home grown grapes in wine inventory were found. One is to record the actual production costs of the grapes. The other is to record the grape content of wine inventory at 'fair value', based on the cost of similar brought in grapes; in the latter case the profit of the total operation is computed in two parts, the first being a profit on grape production and the seoond on wine production. In California we were told that some wineries have split into two separate companies, a grape producer and a wine producer, so that a profit is shown at the grape production stage and the owners can 'take some cash out of the business' by way of dividend. Thus the accounting policy choice between showing 
grape production either at fair value or at actual cost is effectively one of whether to record the profit on grape production at the stage of transfer to wine production, by the fair value method, or at the stage of final sale of the wine, by the actual cost method. If the tax treatment follows the accounting treatment in this case then managers who chose to increase their ability to pay dividends by the 'fair value' method will similarly incur a tax obligation at an earlier stage, and conversely those who forego the right to early dividends will find an additional cash flow benefit because taxable income will only be recorded when wine is sold. The effect of a move to higher quality wine production is to increase the tax and related cash flow impacts of making this accounting policy choice because of tbe longer stock holding period. This matching of the ability to pay dividends out of profits and taxation of profits has been one of the arguments put forward in favour of a binding link between tax and accounting rules in Germany and in Sweden (Blake \& Gowthorpe 1996).

Both methods give rise to some difficulties in their application. In the case of the actual cost approach accounts are distorted depending on whether the company owns or rents the land; whether or not rent appears in the total cost figure can make a big difference in the apparent profitability of the operation. A possible solution to tbis problem is to include imputed rent in the grape cost figure. Although inappropriate for tax purposes, since the imputed rent cost would be balanced by an equal imputed rent income, and equally inappropiate for financial accounts which report on actual, not hypothetical, transactions, imputed rent might be appropriate 
in the 'opportunity cost' transaction of the management accounts. None of the companies we spoke to had taken tbis step but one, in New Zealand, was considering it. One of New Zealand's leading wine producers, Montana, has recently undertaken a major sale and leaseback of agricultural land in order to reinvest in more land. The company we spoke to was considering a similar sale and leaseback scheme and thought an imputed rent on freehold land would make grape costs comparable to those on the leased land.

A Canadian wine producer who was undertaking a major shift from low to high quality production identified a problem with using prices paid to outside suppliers as a guide to the 'fair value' of own produced grapes. Higher quality grape production involved lower yields per hectare, so that application of the prices paid to outside suppliers who had not upgraded quality failed to reflect the full value of the company's own produce. The solution adopted was to allow a 'quality premium' for the higher quality grapes.

To summarise, the impact of the move to higher quality on grape valuation has been:

I . To expand the time lag between profit recognition at the time of grape production under the fair value method and at the time of wine sale under the actual cost method While each method continues to be equitable for tax and financial 
accounting purposes, for management accounting purposes the greater time lag may constitute an argument for using 'fair value' rather than 'actual cost'.

2. Where 'fair value' is the valuation basis for grape production then some system of enhanced value is necessary when quality is upgraded 


\section{The Inflation Effect}

In times of high inflation historic cost accounts can be highly misleading. This problem arises because of the combination of two concepts:

1. The 'money measurement' concept involves measuring all items in the accounts in monetary units. In times of inflation this is like taking a series of measurements over a period of time with a shrinking tape measure.

2. The 'historic cost' convention involves measuring all items on the basis of their actual cost when they are first recorded in the books of accounts. In times of inflation this means that the amount at which items have been recorded becomes steadily less realistic as time passes.

The accounting community have responded to tbis challenge with two alternative approaches:

a) A change to the money measurement convention by changing to a 'current purchasing power' (CPP) unit of measurement.

b) A change to the historic cost convention by adopting a 'current cost', in practice normally replacement cost, basis of measurement. 
A survey in the early 1970s found that most accountants in professional practice preferred a CPP approach, while management accountants tended to prefer a CCA approach. (McCrae \& Dobbins 1974)

Other authors report on the inflation accounting debate in the UK arguing that when inflation is below $10 \%$ there is litle interest in the topic of inflation accounting. Since the early 1980's inflation in most developed economies has been held below this level, and so the issue has not been extensively discussed. This approach ignores evidence that even at inflation levels below 5\% historic cost accounts are misleading. (See Pearcy 1970, Rosenfield 1969) All the countries in our survey currently have low inflation levels. A typical response, expressed in similar terms in both the USA and New Zealand, has been that:

1. It is some 15 years since the accounting profession have seen inflation accounting as a serious issue.

2. The wine industry has not been seen as a special case for the purpose of inflation accounting.

We foumd just one Spanish and one Australian winery that uplift inventory valuation on a replacement cost basis; both focus on high quality production with long stock holding periods, and so have found historic cost stock valuations grossly misleading. 
We would argue that in the wine industry long stock holding periods made the even low levels of inflation distort the historic cost accounts. Example I illustrates this point. At a tax rate of $35 \%$ tbe income tax on the profit of one bottle of wine would be:

$35 \% \times 100=35$ m.u.

However, if we accept that to continue as a going concern inventory sold must be replaced then a 'true' profit is only $77.2 \mathrm{~m}$.u. so that the effective tax rate is

35

$\frac{35}{77.2}=45 \%$

There is material inequity here. The low quality wine producer turning over stock within one year is paying tax at the official rate of $35 \%$; the high quality producer is effectively paying $45 \%$. There is also inequity between industries. For an industry with a stockholding period of less than one year the impact of a low inflation rate on stockholding costs is not material. For quality wine producers, who may hold stock for up to 10 years, even a low inflation rate has a serious distorting effect on historic cost profit measurement. 


\section{Example 1}

\section{Inflation Effect}

A company produces wine with a production cost of 200 monetary units (m.u.) per bottle. After the year of production storage costs are 10 m.u. per bottle per year. Inflation runs consistently at $2 \%$ per year. At the beginning of year 7 the stock is sold for 350 m.u.

\section{Components of Uplift factor \\ cost at \\ end of year 6}

$\begin{array}{cccc}\text { Year 1 } & 200 & 1.104 & 220.8 \\ \text { Year 2 } & 10 & 1.082 & 10.8 \\ \text { Year 3 } & 10 & 1.061 & . \\ \text { Year 4 } & 10 & 1.04 & 10.6 \\ \text { Year 5 } & 10 & 1.02 & 10.4 \\ \text { Year 6 } & \underline{10} & 1 & \underline{10} \\ & \underline{250} & & \underline{272.8}\end{array}$




$\begin{array}{lcc} & \begin{array}{c}\text { Profit ignoring } \\ \text { inflation }\end{array} & \begin{array}{c}\text { Profit } \\ \text { excluding } \\ \text { inflation }\end{array} \\ \text { Sales } & 350 & 350 \\ \text { Cost of sales } & \underline{250} & \underline{277,8} \\ \text { Profit } & \underline{100} & \underline{77,2}\end{array}$

The appropiate solution to this problem depends on the type of accounts considered. In the tax accounts three possible solutions might be considered:

1. In the USA 'Last in First out' stock valuation has minimised the impact of inflation on inventory movements in the profit and loss account, but at the expense of serious inventory understatement in the balance sheet. For wine a 'Next in First out' measure may be more appropiate, given the steady increase in volumes of high quality stock

2. In the UK in the 1970's a system of 'stock appreciation relief gave a crude approximation of the impact of inflation on the cost of sales figure. It is significant that this tax relief was not computed on the same basis as the 'cost of sales adjustment' developed by the accounting profession for CCA accounts; it appears that such a value based adjustment was seen as too subjective to provide a reliable 
basis for taxation. France still has such a system, but it is only triggered off when cost rises over 2 years exceed $10 \%$.

3. A number of countries have developed a system to cope with the impact of inflation on fixed asset costs by allowing occasional or annual tax free revaluations of assets by specified indices followed by fully tax allowable depreciation on the revalued amount. In Spain, for example, such a system operated every few years until 1983, and has recently been revived on an anual basis. Given that the length of time high quality wine inventory is held is longer than the life of many fixed assets, the same system could fairly be applied.

In order to fairly present the accounts of a wine producer we would suggest:

1. That for tax purposes one of the three approaches above be applied to wine inventory held for a period in excess of one year.

2. That in the published accounts tax free inventory revaluations to reflect pnce changes be made, either on a CPP or a CCA basis.

3. That in the management accounts the relevant inventory figure for decision making is one on a replacement cost basis.

\section{Imputed Interest}


The problem of imputed interest is most easily understood by analogy with fixed assets. When a fixed asset is constructed by a business for its own use many countries allow 'capitalisation' of interest on the borrowings that finance the asset. Once construction is complete, tbe asset is put into use and starts to generate income. Consequently capitalisation of interest ceases, and interest costs are charged to the profit and loss account as a cost, matching the income generated by the asset. As we have seen, quality wine inventory is held for periods equal or in excess of many fixed asset lives, the difference being that the wine only generates income at the point in time where a sale is made and the asset leaves the ownership of the company. Thus it would seem appropiate to capitalise interest costs on wine production up to the point of sale.

Example 2 shows a simple example of how interest on wine inventory might be computed. From year 2 to year 6 an amount of 'imputed interest' is deducted from the finance expense for the year and added to the inventory value. On this basis profit on the wine sale is 40 monetary units.; If the issue of imputed interest is ignored then the finance costs of years 2 to 6 will include a total of 60 monetary units of interest that have been incurred in order to keep inventory income on which will only appear in the accounts of year 7, producing an apparent profit of 100 monetaty units.

\section{Example 2}




\section{Imputed Interest}

A company produces wine with a production cost of 200 monetary units (m.u.) per bottle. After the year of production storage costs are 10 m.u. per bottle per year. The company estimates the finance cost at $5 \%$ per year. At the beginning of year 7 the stock is sold for 350 m.u.

$\begin{array}{cccc}\text { Initial } & \text { Imputed } & \text { New Cost in } & \text { Closing Sock Cost } \\ \text { Stock } & \text { interest @ 5\% } & \text { Year } & \text { m.u. } \\ \text { Cost } & \text { m.u. } & \text { m.u. } & \end{array}$

Year 1

Year 200

Year 3220

Year 4241

Year $5 \quad 263$

Year 6286
$-$

10

11

12

13

14

$\underline{60}$
200

10

10

10

10

10

$\underline{250}$

\section{With imputed Without imputed interest interest}

$\begin{array}{lcc}\text { Sale } & 350 & 350 \\ \text { Cost } & 310 & 250 \\ \text { Profit } & \underline{40} & \underline{100}\end{array}$

Rather to our surprise, the only country where we found imputed interest in wine inventory was tbe USA. Imputed interest was allocated to inventory for both tax 
and management accounting purposes, but not in the financial accounts. We would disagree with this approach:

1. Since cash flows from wine inventory only appear when it is sold, it would seem reasonable for tax purposes to allow the whole interest cost as it is paid out and to tax a profit on inventory excluding imputed interest when a sale takes place.

2. In tbe financial accounts the omission of imputed interest from wine inventory means that the interest expense is not matched with the related income. Thus in our simple example, years 2 to 6 would show finance costs unrelated to the generation of income in those years. In year 7 tbe accounts similarly overstate income by failing to show the related finance cost. We would therefore argue for the inclusion of imputed interest on wine inventory in the financial accounts.

3. In the management accounts we would agree with the imputation of interest, as argued above.

\section{Barrel Depreciation}

High quality wine production involves tbe use of a mix of types of barrel at widely varying costs. Thus a Californian wine maker offered these price estimates for barrels:

French Oak $\$ 650$ 


\section{American Oak $\$ 250$}

For tax purposes tbe barrels were deemed to have a life of 7 years, with straight line depreciation. This might be a fair allocation for a low quality producer, using barrels purely for storage. For a high quality producer, where the absortion of flavour from the barrel is an essential element in the production process, a much shorter life is appropiate. Our Californian example used a 3 year life for financial and management accounts; one New Zealand example went as low as 2 years. The only country with an adequate system of tax relief for barrel usage we found was Australia, with barrels depreciated for tax purposes on a $50 \%$ reducing balance rate.

Different wines involve different cost barrels in their production. In our Californian example the company included this distinction in the inventory costing in the management accounts but not in the financial accounts. The result was an interesting contrast between acoounting methods for tax, financial accounting, and management accounting as shown in Table 2.

Table 2

A Califonian wine producer -

\section{Variations in Accounting Practice}

\begin{tabular}{|l|l|l|} 
Tax Accounts & Financial & Management \\
\hline
\end{tabular}




\begin{tabular}{|l|c|c|c|}
\hline $\begin{array}{l}\text { Imputed interest in } \\
\text { inventory? }\end{array}$ & Yes & Accounts & Accounts \\
\hline $\begin{array}{l}\text { Barrels depreciated } \\
\text { over }\end{array}$ & 7 years & 3 years & Y years \\
\hline $\begin{array}{l}\text { Distinction between } \\
\text { barrel type in } \\
\text { inventory valuation? }\end{array}$ & No & No & Yes \\
\hline
\end{tabular}

By contrast one New Zealand winery we visited had a firm policy of using the same accounting measures for tax, financial accounting, and management accounting. However, with the move to higher quality production they were finding their accounts to be increasingly unrealistic and were considering changes to this policy.

In summary, the different pattern of barrel consumption in high quality wine production justifies consideration being given to faster tax depreciation.

\section{Conclusion}

Within the continental European tradition the idea that different industries have distinctive accounting needs is well established. Both France and Spain, for example, have special sectoral plans for some industries. In the Anglo-American tradition, by contrast, the idea has not become established. In Australia, Canada, the USA and New Zealand when asked whether any special accounting guidance for 
the wine industry had been accepted we were told that companies were happy to accept Generally Accepted Accounting Principles (GAAP). Our study indicates that the application of a traditional accounting framework in the wine industry has a negative effect on high quality as compared to low quality producers. Both in order to achieve equity and to promote higher quality production major amendments to tax rules, financial accounting, and management accounting are needed. 


\section{References}

Abdel-Khalik A.R. 1981. "The Economic Effects on Lessees of FASB Statement Number. 13 Accounting of Leases". Standard C T : Financial Accounting Standards Board.

Blake J, Amat O, \& Clarke J. 1995 "Managing the economic impact of accounting regulations: the Spanish case". European Business Review, 95, 6, pp. 26-34.

Blake J, Gowthorpe C. 1996. "Sweedish accounting and the European Union" Company Accountant, December, pp. 18-21 \& 24.

Keane S M. 1983. Stockmarket efficiency: Theory, evidence and implications. Oxford: Philip Allan.

McCrae T \& Dobbins R. 1974. "Behavioural aspects of the inflation accounting controversy" Accounting and Business Research, Spring, pp.135-140

McGee R W. 1984 "Software Accountancy, Bank Lending decisions, and Stock Prices" Management Accounting (US), July, pp 20-23.

Milnes A \& Tillett D. 1978. "Property company accounts" London: Institute of Chartered Accountants in England and Wales.

Pearcy J. 1970 "Inflation and UK published accounts", Journal, UEC, October, pp. 196-203.

Rosenfield, P.1969. "Accounting for inflation - a field test". Journal of Accountancy, June, pp.45-50.

Slepian S. 1985. "How a proposed accounting change threatened an industry". Management accounting, November, pp 47-51.

Wilkins T \& Zimmer I. 1983. "The effects of leasing and different methods of accounting for leases on credit evaluations" Accounting Review, October, pp.749764. 